\author{
Abstracta Iranica \\ Abstracta Iranica Revue bibliographique pour le domaine irano-aryen \\ Volume 37-38-39 | 2018 \\ Comptes rendus des publications de 2014-2016
}

\title{
Fabrice Bouzid-Adler. « Les marines des peoples d'origine louvite à l'époque achéménide »
}

\section{Astrid Nunn}

\section{(2) OpenEdition}

\section{Journals}

Édition électronique

URL : http://journals.openedition.org/abstractairanica/42612

DOI : 10.4000/abstractairanica.42612

ISBN : 1961-960X

ISSN : 1961-960X

Éditeur :

CNRS (UMR 7528 Mondes iraniens et indiens), Éditions de l'IFRI

Référence électronique

Astrid Nunn, « Fabrice Bouzid-Adler. « Les marines des peoples d'origine louvite à l'époque achéménide » », Abstracta Iranica [En ligne], Volume 37-38-39 | 2018, document 19, mis en ligne le 10 mars 2018, consulté le 28 septembre 2020. URL : http://journals.openedition.org/abstractairanica/ 42612 ; DOI : https://doi.org/10.4000/abstractairanica.42612

Ce document a été généré automatiquement le 28 septembre 2020

Tous droits réservés 


\title{
Fabrice Bouzid-Adler. « Les marines des peoples d'origine louvite à l'époque achéménide »
}

\author{
Astrid Nunn
}

\section{RÉFÉRENCE}

Fabrice Bouzid-Adler. « Les marines des peoples d'origine louvite à l'époque achéménide ». Res Antiquae XI, 2014, p. 9-26.

Ce sont les Phéniciens qui viennent à l'esprit quand il s'agit des bateaux requis par les Grands Rois. Et pourtant d'autres régions maritimes telles la Carie, la Lycie et la Cilicie appartenaient à l'empire achéménide. L'A. s'intéresse à leur fonds de population louvite, qui d'une part combattit les Achéménides, mais d'autre part les pourvut de marins et de bateaux. La documentation est très faible, mais $20 \%$ des effectifs totaux auraient pu être louvites. Les bateaux utilisés ressemblaient peut-être à la «fameuse » galère gréco-orientale représentée sur un des reliefs de Karatepe.

\section{AUTEURS}

\section{ASTRID NUNN}

Université de Munich 